\title{
Physiological indexese macro- and micronutrients in plant tissue and essential oil of Mentha piperita L. grown in nutrient solution with variation in N, P, K and Mg levels
}

\author{
David, E.F.S. ${ }^{1 *}$; Mischan, M.M. ${ }^{2}$; Marques, M.O.M. ${ }^{3} ;$ Boaro, C.S.F. ${ }^{4}$ \\ ${ }^{1 *}$ Faculdades Integradas de Bauru (FIB-Bauru) evelizedavid@yahoo.com.br; ${ }^{2}$ Instituto de Biociências, \\ Departamento de Bioestatistica, UNESP-Botucatu; ${ }^{3}$ Instituto Agronômico de Campinas, Centro de Pesquisa \\ e Desenvolvimento de Recursos Genéticos Vegetais, Fitoquímica; ${ }^{4}$ Instituto de Biociências, Departamento de \\ Botânica, UNESP-Botucatu.
}

\begin{abstract}
Mentha piperita L. is an aromatic and medicinal species of the family Lamiaceae, known as mint or peppermint, and its leaves and branches produce essential oil rich in menthol. This study aimed to evaluate physiological indexes, macro- and micronutrients inthe shootsand essential oil of Mentha piperita L. grown in nutrient solution number 2 of Hoagland and Arnon (1950) with different N, P, K and Mg levels. Shoot length, dry mass of the different organs, total dry mass, leaf area, essential oil yield and composition, and macronutrient $(\mathrm{N}, \mathrm{P}, \mathrm{K}, \mathrm{Mg}, \mathrm{Ca}, \mathrm{S})$ and micronutrient $(\mathrm{Mn}, \mathrm{Cu}, \mathrm{Fe}, \mathrm{Zn})$ contents in the shoot were evaluated. Plants treated with $65 \% \mathrm{~N} / 50 \% \mathrm{P} / 25 \% \mathrm{~K} / 100 \% \mathrm{Mg}$ had a tendency towards longer shoot, greaterroot and leaf blade dry masses, higher essential oil yield, higher menthol levels and lower menthone levels. The results showed that Mentha can be grown in nutrient solution by reducing $65 \% \mathrm{~N}, 50 \% \mathrm{P}, 25 \%$ $\mathrm{K}$ and $100 \% \mathrm{Mg}$. This solution had better development compared to the other tested treatments. Therefore,we recommendMentha piperita $\mathrm{L}$. to be grown with such nutrient levels.
\end{abstract}

Keywords: Lamiaceae, menthol,hydroponics and nutrition

RESUMO: Índices fisiológicos, macro e micronutrientes no tecido vegetal e óleo essencial de Mentha piperita L. cultivada em solução nutritiva com variação de N, P, K e Mg. Mentha piperita L., é uma espécie aromática e medicinal pertencente à família Lamiaceae, conhecida como menta ou hortelã-pimenta que produz em sua parte aérea óleo essencial rico em mentol. $\mathrm{O}$ objetivo do trabalho foi avaliar os índices fisiológicos, macro e micronutrientes na parte aérea e óleo essencial de Mentha piperita L. cultivada em solução nutritiva numero Hoagland e Arnon (1950) com variação dos níveis de N, P, K e Mg. Foram avaliados comprimento da parte aérea, massa seca dos diferentes órgãos e total, área foliar, rendimento e composição do óleo essencial, teor de macronutrientes ( $\mathrm{N}, \mathrm{P}, \mathrm{K}, \mathrm{Mg}, \mathrm{Ca}$ e S), e de micronutrientes ( $\mathrm{Mn}, \mathrm{Cu}, \mathrm{Fe}$ e $\mathrm{Zn}$ ) na parte aérea. As plantas nutridas com $65 \%$ de N, 50\% de P, $25 \%$ de $\mathrm{K}$, e $100 \%$ de $\mathrm{Mg}$, apresentaram tendência de maior comprimento de parte aérea e massa seca de raízes e de lâminas foliares; maior rendimento de óleo essencial e, em média, maiores teores de mentol e menores teores de mentona. O resultados permitem concluir que a Mentha pode ser cultivada em solução nutritiva reduzindo-se $65 \%$ de N, $50 \%$ de P, $25 \%$ de $\mathrm{Ke} 100 \%$ de $\mathrm{Mg}$. Esta solução apresentou melhor desenvolvimento em relação aos outros tratamentos. Recomenda-se, portanto, o cultivo da Mentha piperita L. com tais níveis de nutrientes.

Palavras-chave: Lamiaceae, mentol, hidroponia e nutrição

\section{INTRODUCTION}

Commonly known as mint or peppermint, Mentha piperita $\mathrm{L}$. is an aromatic plant of the family Lamiaceae (Lorenzi and Matos, 2002). The plants of this family have been extensively studied from an agronomical and chemical point of view due to their richness in essential oils, and the aims of these studies have been not only to maximize their essential oil content, but also to assess the variation in their oil compounds (Martins, 2002), which may completely change the oil quality.

The essential oil is originated in the secondary metabolism of the plant; however, the compounds 
of this pathway depend on the primary metabolism. Thus, plant productivity, which reflects the primary metabolism and it is determined by biomass gain, depends on leaf quantity, photosynthetic capacity of each leaf and nutrient availability. The suitable supply of mineral nutrients for the culture is one of the most important factors to increase productivity (Fageria et al., 1997).

Thus, aromatic plants developed in hydroponics, with all nutrients available, had higher productivity and accumulated from 3 to 6 -fold more essential oil per area, relative to plants grown using the traditional method (Mairapetyan, 1999). Essential oil content can usually be increased with no need of additional production costs; therefore, appropriate propagation and cultivation forms that provide better oil yield have been the object of a number of studies (Martins, 2002).

Chemical and physical variations in the compounds of mint essential oil may occur since it is a mixture of compounds of different natures accumulated by the plant at specific rates. Thus, the content of the substances present in the oil is highly dependent on environmental factors, and plants developed under different conditions may contain oils with different characteristics (Maia, 1998). The qualitative and quantitative composition of the oil from medicinal plants may vary during the growth phases (Castro et al., 2001).

Several studies have shown the importance of mineral nutrition in the development of species of the family Lamiaceae and the content and composition of their essential oil. Some researchers have evaluated $M$. piperita in hydroponic culture with different Nitrogen $(N)$, Phosphorus $(P)$, Potassium (K) and Magnesium $(\mathrm{Mg}$ ) concentrations (Mairapetyan et al., 1999; David et al., 2006; Valmorbida et al., 2006; David et al., 2007; Valmorbida and Boaro, 2007; Valmorbida et al., 2007). Those authors noted that, regardless of the studied nutrient, its variation in the nutrient solution frequently interferes with the species development and oil yield by decreasing or increasing the oil content and varying its composition. As the secondary metabolism, oil synthesis depends on compounds synthesized in the primary metabolism and plant productivity is determined by the quantity of leaves and their photosynthetic capacity, as well as nutrient availability, which are key factors for biomass gain. Milthorpe and Moorby (1974) stated that the deficiency of a nutrient interferes with the final production, although the intermediate physiological variables that are compromised remain not fully understood (Marschner, 2012). The efficiency of plants in obtaining a nutrient at a quantity sufficient for their growth depends not only on the available level of this element in the nutrient medium, but also on external factors associated with the environmental and physiological factors affecting absorption (Epstein and Bloom, 2006). Among these external factors are the element itself and its level relative to the other elements in the substrate. Studies have emphasized the importance of nutrient balance in the medium and have frequently reported interactions between nutrients which may be harmful to the plants. Thus, unbalanced concentrations of nutrients reciprocally influence their availability, uptake and transport in the plant (Marschner, 2012). In addition to nutrient availability, the appropriate elemental ratio must be considered to ensure optimal plant growth (Marenco et al., 2001).

Over the years, several formulations have been employed in nutrient solutions and that of Hoagland and Arnon (1950) contains all mineral elements known to be necessary for the rapid growth of plants. These elements are established at the highest allowed levels, without causing symptoms of toxicity or salt stress (Zeiger, 2004). To obtain a product of higher quality, Leal, 2001; David et al., 2006; Valmorbida et al., 2006; David et al., 2007; Valmorbida and Boaro, 2007; Valmorbida et al., 2007 , used that solution with a modification in $\mathrm{N}$, $\mathrm{P}$ and $\mathrm{K}$ content, respectively, and concluded that nitrogen levels above those recommended for solution number 2 of Hoagland and Arnon (1950) interfered with the development of $M$. piperita and decreased the yield and quality of its essential oil. $P$ levels reduced to $50 \%$ and potassium levels reduced to $75 \%$ led to higher essential oil yield.

Based on the results obtained in the above-mentioned studies and considering that nutrient solution of Hoagland and Arnon number 2 overestimates the content of macronutrients, modifications were done to establish the different treatments evaluated in the present study. The modified nutrient solution with variation in the level of macronutrients $\mathrm{N}, \mathrm{P}, \mathrm{K}$ and $\mathrm{Mg}$ and their relationship were used for $M$. piperita culture, allowing the establishment of a solution that is more appropriate for the development of this species.

Thus, the aim of the study was to evaluate the physiological indexes, macronutrient $(\mathrm{N}, \mathrm{P}, \mathrm{K}$, $\mathrm{Mg}, \mathrm{Ca}$, and $\mathrm{S}$ ) and micronutrient (Mn, $\mathrm{Cu}, \mathrm{Fe}$, and $\mathrm{Zn}$ ) contents in the shoot and the essential oil of $M$. piperita grown in nutrient solution with a variation in $\mathrm{N}, \mathrm{P}, \mathrm{K}$ and $\mathrm{Mg}$ levels.

\section{MATERIAL AND METHODS}

The experiment was carried out in a PaddyFan-type greenhouse at the Department of Botany, Institute of Biosciences, UNESP - Universidade Estadual Paulista, Botucatu Campus, São Paulo State, Brazil.

The geographical coordinate this experiment 
was performed was $22^{\circ} 49^{\prime} 10^{\prime \prime} \mathrm{S}, 48^{\circ} 24^{\prime} 35^{\prime \prime} \mathrm{W}$ and altitude is $800 \mathrm{~m}$.

M. piperita seedlings were obtained from matrix plants of ESALQ, USP - Universidade de São Paulo, located in Piracicaba, São Paulo State, Brazil, and were propagated first in pots then in beds to obtain the adequate material quantity to perform the experiment.

Aerial branches of these plants were selected to prepare $10 \mathrm{~cm}$-length apical cuttings with the first four leaves pairs. After being disinfected through rapid immersion in sodium hypochlorite $(\mathrm{NaClO})$ solution at $2,0 \%$, these cuttings were washed in running water and stored in potassium nitrate $\left(\mathrm{KNO}_{3}\right)$ solution at $600 \mathrm{mg} \mathrm{L}^{-1}$ for 10 days, time needed for rooting (Soares and Sacramento, 2001).

Rooted cuttings were transferred to pots with nutrient solution no 2 of Hoagland and Arnon (1950), modified by the variation in N, P, K and Mg concentrations, constituting the different treatments to which plants were subjected: the treatment with $50 \% \mathrm{~N}, \mathrm{P}, \mathrm{K}$ and $25 \% \mathrm{Mg}$ (designated $50 \% \mathrm{~N} / \mathrm{P} /$ $\mathrm{K} / 25 \% \mathrm{Mg}$ ) had, in $\mathrm{mg} \mathrm{L}^{-1}, 94.0 \mathrm{~N} / 15.5 \mathrm{P} / 107.5$ $\mathrm{K} / 12.15 \mathrm{Mg}$; the treatment with $50 \% \mathrm{~N}, \mathrm{P}, \mathrm{K}$ and $\mathrm{Mg}$ $(50 \% \mathrm{~N} / \mathrm{P} / \mathrm{K} / \mathrm{Mg})$ had $94.0 \mathrm{~N} / 15.5 \mathrm{P} / 107.5 \mathrm{~K} / 24.3 \mathrm{Mg}$; the treatment with $65 \% \mathrm{~N}, 50 \% \mathrm{P}, 25 \% \mathrm{~K}$ and $100 \%$ $\mathrm{Mg}(65 \% \mathrm{~N} / 50 \% \mathrm{P} / 25 \% \mathrm{~K} / 100 \% \mathrm{Mg})$ had $124.0 \mathrm{~N} / 15.5$ $\mathrm{P} / 53.6 \mathrm{~K} / 48.6 \mathrm{Mg}$; and the treatment with $100 \% \mathrm{~N}, \mathrm{P}$, $\mathrm{K}$ and $\mathrm{Mg}(100 \% \mathrm{~N} / \mathrm{P} / \mathrm{K} / \mathrm{Mg})$ had $189.0 \mathrm{~N} / 31.0 \mathrm{P} / 214.5$ $\mathrm{K} / 48.6 \mathrm{Mg}$. pH was kept between 5.5 and 6.0 and the solution electrical conductivity between 1.5 and $2.5 \mathrm{mS} \mathrm{cm}^{-1}$, according to the recommendations of Carmello (1992). The nutrient solution, continuously aerated using a rotary blower, was renewed at every two weeks. Whenever needed, the solution volume in the pots was completed with water.

Experimental design was a completely randomized, with four replicates, with one plant each, in a $4 \times 5$ factorial scheme, i.e., four treatments and five harvest periods, at 20,35, 50, 65 and 85 days after transplant (DAT). For the essential oil, the design was completely randomized with four replicates in $4 \times 4$ factorial arrangements, i.e. four treatments and four harvest periods, at 69, 84, 98 and 113 DAT. The results were evaluated by factorial analysis of variance and regression analysis, means were compared by Tukey test at $5 \%$ significance level (Zar, 2009). The variables length, leaf area, dry mass of several organs and total dry mass had heterogeneous variance among treatments; thus, weighted regression analysis and log-transformation of the results were used for analysis of variance.

In all harvests, the plants had their shoot length measured and the leaf area of all their leaves determined, according to David et al. (2007), and they were separated into roots, stems, petioles and leaf blades. Leaf blades area was determined using an area meter, model LI 3100, LI-COR, in $\mathrm{dm}^{2}$. All organs were stored in labeled paper bags and allowed to dry in forced-aeration oven at a temperature between 60 and $70^{\circ} \mathrm{C}$ until constant mass was obtained. When completely dried, the material was weighed for dry mass determination. Leaf blades and stems plus petioles were ground to prepare the extracts according to Malavolta et al. (1997) for the determination of shoot macro and micronutrients.

To determine the essential oil yield, plants were harvested at 69, 84, 98 and 113 DAT, weighed, stored in paper bags and placed in forced-aeration ovens at $40^{\circ} \mathrm{C}$ for three days. On the third day, the dry mass was determined through hydrodistillation in Clevenger-type. M. piperita shoot dry mass (30 g) was added to a $2000 \mathrm{~mL}$ flat-bottomed flask and water was added until the sample was covered; then, the sample was heated for one and a half hour. After extraction, essential oil yield was calculated based on the difference between the final and the initial mass of the flask. As this difference corresponded to the oil extracted from $30 \mathrm{~g}$ shoot dry mass, the yield was estimated for $100 \mathrm{~g}$ of its mass.

\section{RESULTS AND DISCUSSION}

The nutrient solutions treatment $50 \% \mathrm{~N} / \mathrm{P} /$ $\mathrm{K} / 25 \% \mathrm{Mg}$ resulted in plants with a tendency to decreased shoot length (Figure 1a), leaf area (Figure $1 \mathrm{~b}$ ), dry mass of different organs (Figure 1c and Figure 2a, 2b and 2c) and essential oil yield (Table 1 ), with no signs of deficiency of these nutrients, although minor differences in nutrients were detected for shoots (Tables 2 and 3 ).

Plants grown with $50 \% \mathrm{~N} / \mathrm{P} / \mathrm{K} / \mathrm{Mg}$ had a tendency towards increase of leaf area (Figure 1b) and root dry mass at 65 DAT (Figure 1c). However, these slight increases did not result in higher dry mass yields or essential oil (Figure $2 \mathrm{c}$ and Table 1 ). These plants had lower Mg content in the leaves blade (Table 4) and stems plus petioles, (Table 5 ), with no signs of Mg deficiency. It suggests that despite the decrease of $\mathrm{Mg}$, even in the lowest concentration tested in the nutrient solution, plants had enough of this element to supply its metabolic demands.

Although it is possible to occur substitution of $\mathrm{Mg}$ by other elements in some metabolic processes, it is indispensable in several stages of photosynthesis, with a role related to conversion and maintenance of energy, and regulation effect upon Calvin cycle enzymes (Epstein and Bloom, 2006). The hypothesis that the lowest concentration of $\mathrm{Mg}$ tested supplied the metabolic demands is confirmed by the assessment of $\mathrm{CO}_{2}$ assimilation rate, when this treatment was related to higher assimilation 
(Figure 3).

The present results agree in part with those obtained by Valmorbida et al. (2007) and David et al. (2007), who grew M. piperita under different levels of $\mathrm{K}$ and $\mathrm{P}$, respectively, and observed higher stem plus petiole dry mass and root dry mass, for plants grown with $50 \%$ reduction in $\mathrm{K}$ and $\mathrm{P}$ levels. These results also corroborate those of Valmorbida et al. (2007), who observed higher shoot length in plants grown with $50 \% \mathrm{~K}$ reduction. It must be emphasized, however, that in the present study the reductions were simultaneous for $\mathrm{N}, \mathrm{P}$ and $\mathrm{K}$, whereas in the remaining studies the reduction was for only one of the minerals. Santos et al. (2002) grew Ocimum

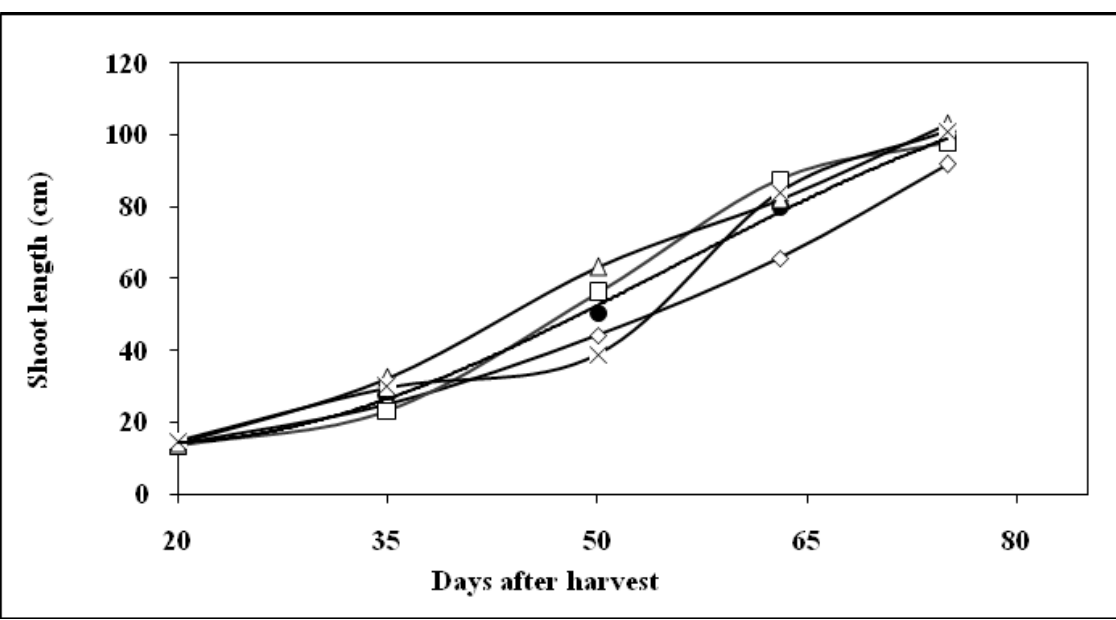

Yt1 $=0,019^{*} \operatorname{EXP}(0,445 x-0,007 \times 2)$

$\mathrm{R} 2=0,998$

$Y t 2=2.950 * \operatorname{EXP}(0,080 x-0,00045 \times 2)$

$\mathrm{R} 2=0,990$

Yt3 $=4,82^{*} E X P(0,059 x-0,00028 \times 2)$

$\mathrm{R} 2=0,986$

Yt4 $=5,43^{*} \operatorname{EXP}(0,055 x-0,00024 \times 2)$

$\mathrm{R} 2=0,985$

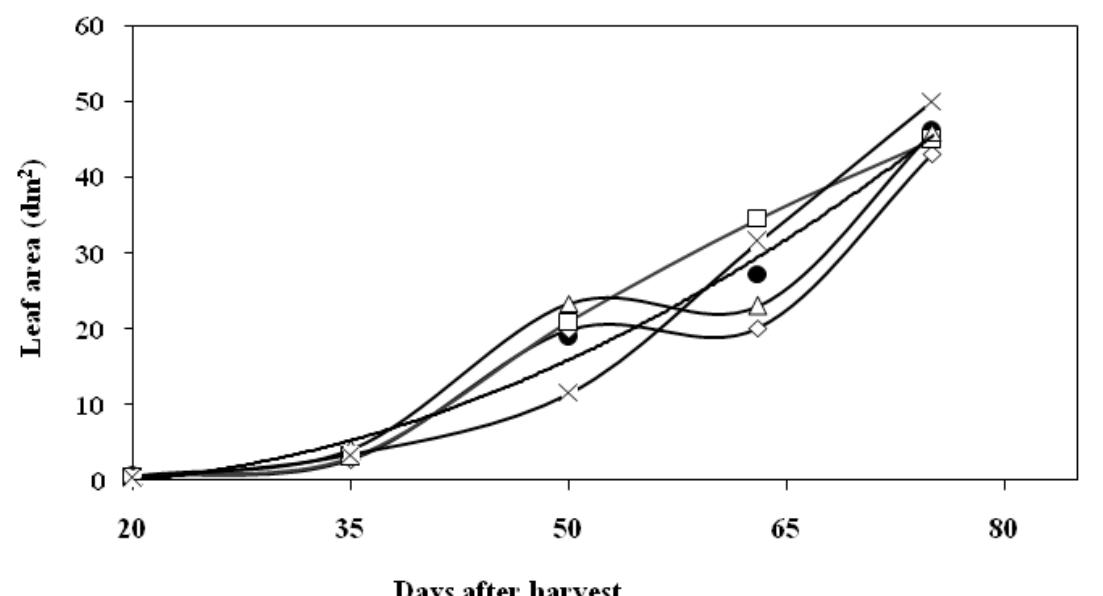

$\mathrm{Yt} 1=0,014^{\star} \operatorname{EXP}(0,530 \mathrm{x}-0,0095 \times 2)$

$\mathrm{R} 2=0,981$

$Y t 2=0,011^{*} \operatorname{EXP}(0,22 x-0,0014 x 2)$

$\mathrm{R} 2=0,995$

$Y \mathrm{t} 3=0,0147^{*} \operatorname{EXP}(0,21 x-0,0013 \times 2)$

$\mathrm{R} 2=0,986$

$\mathrm{Yt} 4=0,0023^{*} \mathrm{EXP}(0,25 \mathrm{x}-$ $0,00016 \times 2$ )

$\mathrm{R} 2=0,995$

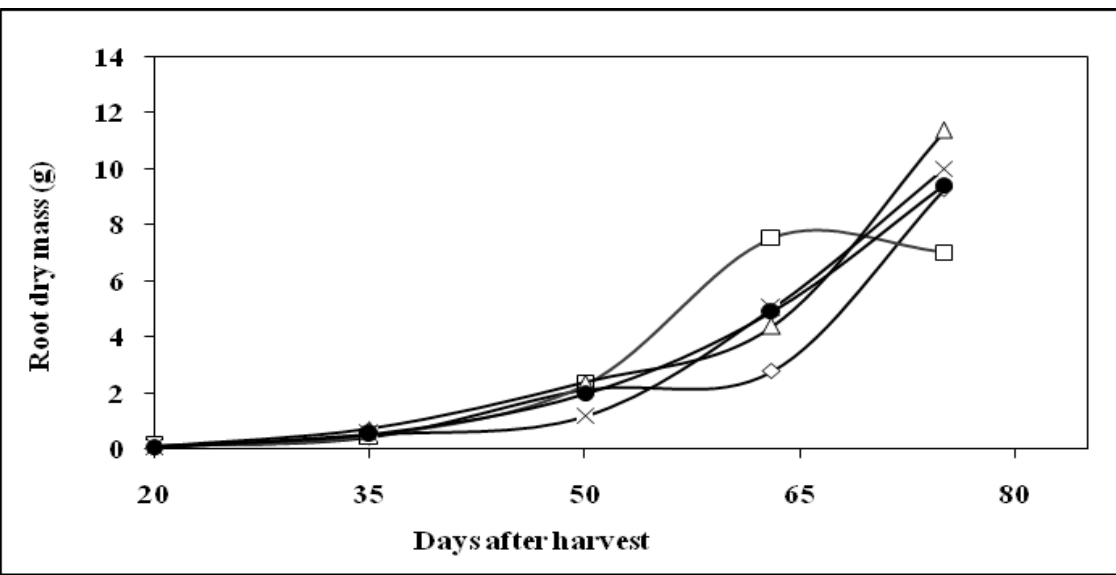

$Y t 1=0,0087^{\star} E X P(0,14 x-0,00064 \times 2)$

$\mathrm{R} 2=0,991$

Yt2 $=0,0028^{*} \operatorname{EXP}(0,20 x-0,0012 \times 2)$

$\mathrm{R} 2=0,993$

$Y \mathrm{t} 3=0,003^{*} \operatorname{EXP}(0,19 x-0,0010 \times 2)$

$\mathrm{R} 2=0,993$

$Y t 4=0,0013^{*} \operatorname{EXP}(0,19 x-0,00108 \times 2)$

$\mathrm{R} 2=0,991$

FIGURE 1. Shoot length, $\mathrm{cm}$ (a), leaf area, dm2 (b) and root dry mass, $\mathrm{g}$ (c) of Mentha piperita L. grown in nutrient solution with different $\mathrm{N}, \mathrm{P}, \mathrm{K}$ and Mg levels, $\mathrm{mg} \mathrm{L-1}$, at several harvests. Curves were adjusted by exponential quadratic equation. 
basilicum in the nutrient solution proposed by Furlani et al. (1999), with nutrient levels inferior and superior to those established for the complete solution; those authors observed the highest heights for plants grown in complete nutrient solution and lower root dry mass for plants grown in solution with $50 \%$ and $75 \%$ nutrient reduction, agreeing in part with the present study.

Plants that received solution containing $65 \% \mathrm{~N} / 50 \% \mathrm{P} / 25 \% \mathrm{~K} / 100 \% \mathrm{Mg}$ had a tendency towards higher shoot length (Figures 1a), root dry mass, leaf blades (Figure 1c and Figure 2b), and essential oil yield (Table 1), compared to those grown with complete solution, which indicates that when

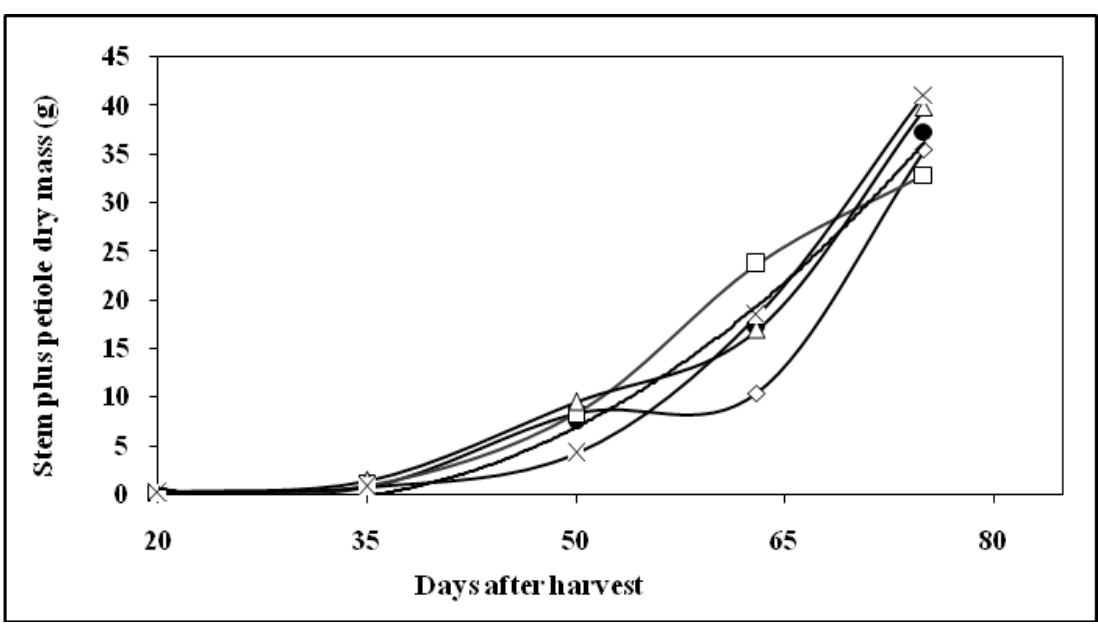

$\mathrm{Yt1}=0,, 23^{*} \operatorname{EXP}(0,056 \mathrm{x}+0,000047 \mathrm{x} 2)$

$\mathrm{R} 2=0,938$

Yt2 $=0,00088^{*} \mathrm{EXP}(0,26 x-0,0016 \times 2)$

$\mathrm{R} 2=0,998$

$\mathrm{Yt} 3=0,0018^{*} \mathrm{EXP}(0,24 \mathrm{x}-0,00114 \times 2)$

$\mathrm{R} 2=0,997$

$\mathrm{Yt} 4=0,0014^{*} \operatorname{EXP}(0,22 \mathrm{x}-0,0012 \times 2)$

$\mathrm{R} 2=0,991$

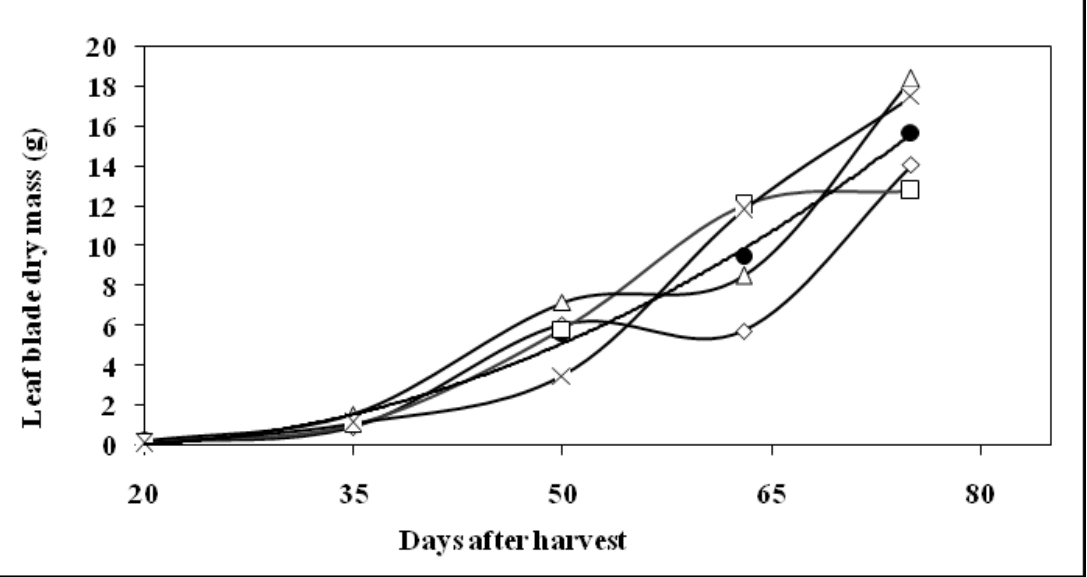

$\mathrm{Yt} 1=0,007^{*} \mathrm{EXP}(0,180 \mathrm{x}-0,00109 \mathrm{x} 2)$

$\mathrm{R} 2=0,984$

Yt2 $=0,0054^{\star} E X P(0,202 x-0,0013 \times 2)$

$\mathrm{R} 2=0,997$

$Y \mathrm{t} 3=0,00166{ }^{*} \mathrm{EXP}(0,19 \mathrm{x}-0,0012 \mathrm{x} 2)$

$\mathrm{R} 2=0,990$

Yt4 $=0,0017^{*} \operatorname{EXP}(0,23 x-0,0014 x 2)$

$\mathrm{R} 2=0,995$

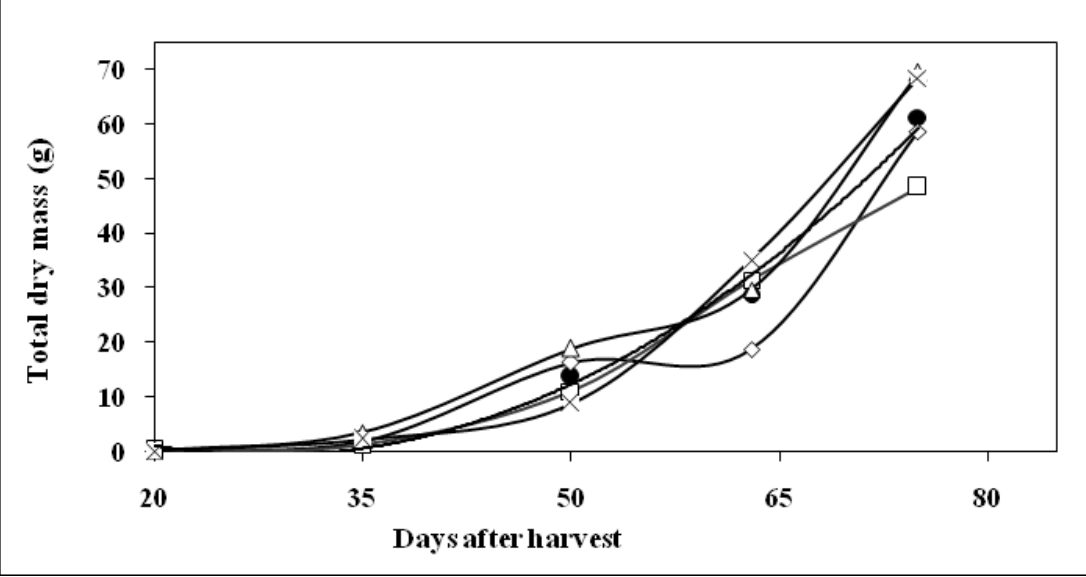

$\mathrm{Yt} 1=0,, 014^{*} \mathrm{EXP}(0,182 \mathrm{x}-$ $0,00100 \times 2)$

$\mathrm{R} 2=0,988$

$Y t 2=0,010^{*} \operatorname{EXP}(0,186 x-0,0010 \times 2)$

$\mathrm{R} 2=0,991$

$Y t 3=0,0097^{*} \operatorname{EXP}(0,210 x-0,0013 \times 2)$

$\mathrm{R} 2=0,995$

$\mathrm{Yt} 4=0,0044$ * EXP $(0,2216 \mathrm{x}-$

$0,0012 \times 2)$

$\mathrm{R} 2=0,996$

FIGURE 2. Stem plus petiole dry mass, $g$ (a), leaf blade dry mass, $g(b)$ and total dry mass, $g$ (c) of Mentha piperita L. grown in nutrient solution with different $\mathrm{N}, \mathrm{P}, \mathrm{K}$ and $\mathrm{Mg}$ levels, $\mathrm{mg} \mathrm{L}^{-1}$, at several harvests. Curves were adjusted by exponential quadratic equation. 
these variables are considered, $M$. piperita can be grown with reduced levels of $\mathrm{N}, \mathrm{P}$ and $\mathrm{K}$ in relation to the complete nutrient solution.

These plants absorbed smaller quantity of $\mathrm{K}$ and larger quantity of $\mathrm{Mg}$, which can be confirmed by the levels of these nutrients in the leaf blades and stems plus petioles (Tables 2 and 3 ). These results show the interaction between $\mathrm{K}$ and $\mathrm{Mg}$, which compete by the root binding sites during absorption (Marschner, 2012).

When an ion is in a higher concentration than another, competition causes decline on absorption rate of the latter. In the present study, higher concentration of $\mathrm{Mg}$ probably caused decrease on $\mathrm{K}$ absorption, without differences on $\mathrm{CO}_{2}$ assimilation (Figure 3 ).

However, these plants that showed no great differences in $\mathrm{CO}_{2}$ assimilation, revealed adequated exports from leaves to branches and petioles, as demonstrated by the evaluation of leaf mass ratio, and confirmed by the distribution of dry mass of branches and petioles (David and Boaro, 2009). Then, the amount of this nutrient offered was adequate, once these plants showed normal growth, with no interference in the translocation of carbohidrates to other organs.

These plants showed higher average yield of essential oil during its cycle (Table 1), showing that secondary metabolism depends on primary metabolism, since oil producing glands are carbon consumers and relies on adjacent photosynthetic cells for the suplly of these precursors (Croteau and Johnson, 1984).

The plants of the present study had a tendency towards higher oil yield on the third harvest, at $98 \mathrm{DAT}$, whereas the plants subjected to treatment $65 \% \mathrm{~N} / 50 \% \mathrm{P} / 25 \% \mathrm{~K} / 100 \% \mathrm{Mg}$ had a tendency towards higher oil yield on the second harvest, at 84 DAT, which may not justify keeping this species longer in the field or in greenhouse since it would increase yield costs and make the plant susceptible to other problems, with the decrease of oil content (Table 1). Thus, the decreased N, P, K and Mg levels in these plants did not damage their physiological functions and were satisfactory to the plant growth, essential oil yield and quality of $M$. piperita.

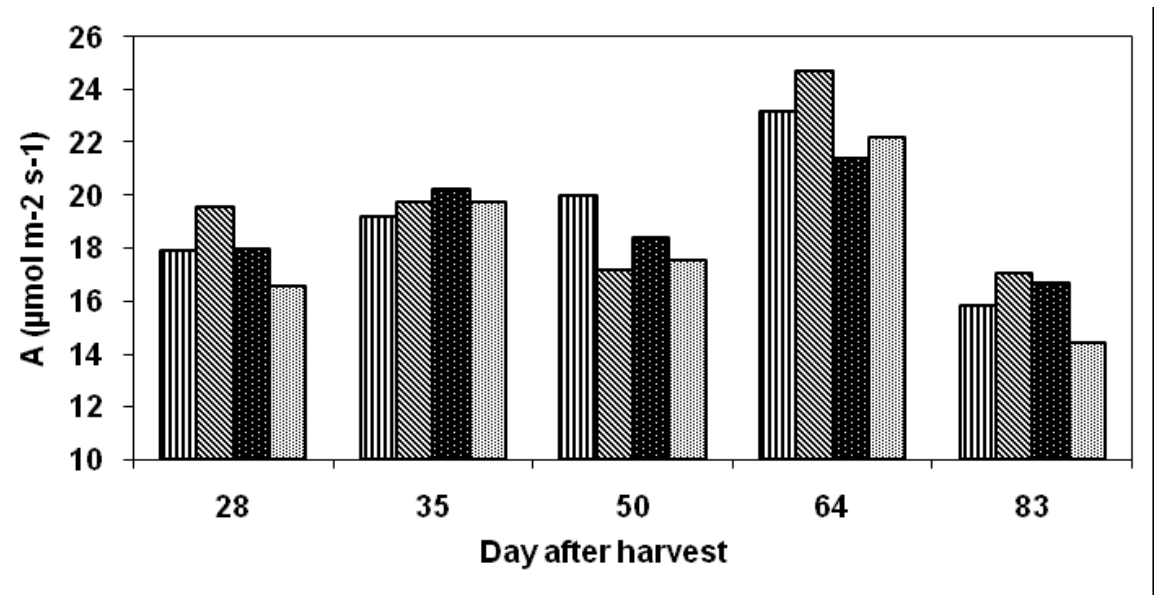

FIGURE 3. Assimilation of $\mathrm{CO}_{2}$ of Mentha piperita L. grown in nutrient solution with different $\mathrm{N}, \mathrm{P}, \mathrm{K}$ and $\mathrm{Mg}$ levels, $\mathrm{mg} \mathrm{L}^{-1}$, at several harvests.

TABLE 1. Comparison among means essential oil yield ( $\mathrm{mg} \mathrm{( \% )} 30 \mathrm{~g}^{-1}$ dry mass) of Mentha piperita L. grown in nutrient solution with different levels of $\mathrm{N}, \mathrm{P}, \mathrm{K}$ and $\mathrm{Mg}$ at the several harvests.

\begin{tabular}{|c|c|c|c|c|c|}
\hline $\begin{array}{l}\mathrm{N} / \mathrm{P} / \mathrm{K} / \mathrm{Mg} \text { levels relative to the complete } \\
\text { solution }\end{array}$ & Harvest ( & ys after tra & ant) & & \\
\hline & $1^{\mathrm{st}}(69)$ & $2^{\text {nd }}(84)$ & $3^{\text {rd }}(98)$ & $4^{\text {th }}(113)$ & $\begin{array}{c}\mathrm{N} / \mathrm{P} / \mathrm{K} / \mathrm{Mg} \text { mean } \\
\text { levels }\end{array}$ \\
\hline $50 \% \mathrm{~N} / \mathrm{P} / \mathrm{K} / 25 \% \mathrm{Mg}$ & $17.288 \mathrm{a}$ & $26.397 \mathrm{a}$ & $30.015 a$ & $24.995 \mathrm{a}$ & $24.675 \mathrm{~b}$ \\
\hline $50 \% \mathrm{~N} / \mathrm{P} / \mathrm{K} / \mathrm{Mg}$ & $20.812 a$ & $23.564 \mathrm{a}$ & $25.151 \mathrm{a}$ & $24.917 \mathrm{a}$ & $23.611 \mathrm{~b}$ \\
\hline $65 \% \mathrm{~N} / 50 \% \mathrm{P} / 25 \% \mathrm{~K} / 100 \% \mathrm{Mg}$ & $32.644 a$ & $39.776 \mathrm{a}$ & $30.494 \mathrm{a}$ & $32.824 \mathrm{a}$ & $33.935 \mathrm{a}$ \\
\hline $100 \%$ N/P/K/Mg (complete) & $18.507 a$ & $25.851 \mathrm{a}$ & $33.425 \mathrm{a}$ & $23.467 \mathrm{a}$ & $25.313 \mathrm{~b}$ \\
\hline Mean of harvests & 22.313 & 28.897 & 29.772 & 26.551 & 26.883 \\
\hline $\mathrm{CV}$ & 31,431 & 17,3099 & 22,962 & 13,293 & \\
\hline
\end{tabular}

Means followed by the same letter on the line do not differ at $5 \%$ significance. On transplant date, seedlings were 10 days old from the establishment of cuttings in $\mathrm{KNO}_{3}$ solution. 
TABLE 2. Comparison among means of macro and micronutrient levels determined in leaf blade of Mentha piperita L. grown in nutrient solution with different $\mathrm{N}, \mathrm{P}, \mathrm{K}$ and $\mathrm{Mg}$ at several harvests periods.

\begin{tabular}{|c|c|c|c|c|c|}
\hline \multirow{2}{*}{$\begin{array}{l}\text { Elements } \\
\text { Macronutrients }\end{array}$} & \multicolumn{5}{|c|}{$\mathrm{N} / \mathrm{P} / \mathrm{K} / \mathrm{Mg}$ levels relative to the complete solution } \\
\hline & $50 \% \mathrm{~N} / \mathrm{P} / \mathrm{K} / 25 \% \mathrm{Mg}$ & $50 \% \mathrm{~N} / \mathrm{P} / \mathrm{K} / \mathrm{Mg}$ & $65 \% \mathrm{~N} / 50 \% \mathrm{P} / 25 \% \mathrm{~K} / 100 \% \mathrm{Mg}$ & $100 \% \mathrm{~N} / \mathrm{P} / \mathrm{K} / \mathrm{Mg}$ & $\mathrm{CV}$ \\
\hline Nitrogen & $42.77 a b$ & 43.33ab & $34.93 a b$ & $28.80 \mathrm{~b}$ & 15.5 \\
\hline Phosphorus & $7.43 a$ & $6.76 a$ & $6.47 a$ & $7.94 a$ & 21.8 \\
\hline Potassium & $31.06 a$ & $29.30 \mathrm{ab}$ & $22.57 \mathrm{~b}$ & $32.04 a$ & 25.2 \\
\hline Magnesium & $4.27 c$ & $5.09 \mathrm{bc}$ & $7.96 a$ & $5.71 b$ & 24.8 \\
\hline Calcium & $13.04 a$ & $14.62 a$ & $15.78 a$ & $14.96 a$ & 38.5 \\
\hline Sulfur & $3.26 a$ & $3.36 \mathrm{a}$ & $3.08 \mathrm{a}$ & $3.28 \mathrm{a}$ & 22.5 \\
\hline \multicolumn{6}{|l|}{ Micronutrients } \\
\hline Manganese & $59.00 \mathrm{ab}$ & $52.00 a$ & $69.25 a$ & $57.00 \mathrm{~b}$ & 21.8 \\
\hline Copper & $95.62 a$ & $102.00 a$ & $99.38 a$ & $89.87 a$ & 20.9 \\
\hline Iron & $172.04 a$ & 159.37ab & $141.75 b$ & $134.75 b$ & 20.7 \\
\hline Zinc & $95.62 a$ & $102.00 \mathrm{a}$ & $99.37 a$ & $89.87 a$ & 20.9 \\
\hline
\end{tabular}

Means followed by the same letter on the line do not differ at $5 \%$ significance. On transplant date, seedlings were 10 days old from the establishment of cuttings in $\mathrm{KNO}_{3}$ solution.

TABLE 3. Comparison among means of macro and micronutrient levels determined for stems plus petioles of Mentha piperita L. grown in nutrient solution with different levels of N, P, K and Mg at several harvests periods.

\begin{tabular}{|c|c|c|c|c|c|}
\hline \multirow{2}{*}{$\begin{array}{l}\text { Elements } \\
\text { Macronutrients }\end{array}$} & \multicolumn{5}{|c|}{$\mathrm{N} / \mathrm{P} / \mathrm{K} / \mathrm{Mg}$ levels relative to the complete solution } \\
\hline & $50 \% \mathrm{~N} / \mathrm{P} / \mathrm{K} / 25 \% \mathrm{Mg}$ & $50 \% \mathrm{~N} / \mathrm{P} / \mathrm{K} / \mathrm{Mg}$ & $65 \% \mathrm{~N} / 50 \% \mathrm{P} / 25 \% \mathrm{~K} / 100 \% \mathrm{Mg}$ & $100 \% \mathrm{~N} / \mathrm{P} / \mathrm{K} / \mathrm{Mg}$ & CV \\
\hline Nitrogen & $23.78 a$ & $23.40 \mathrm{a}$ & $23.24 a$ & $23.89 a$ & 13.8 \\
\hline Phosphorus & $5.01 a$ & $5.16 \mathrm{a}$ & $4.80 a$ & $5.76 a$ & 21.2 \\
\hline Potassium & 29.82ab & $33.03 a$ & $23.91 \mathrm{~b}$ & $35.24 a$ & 27.4 \\
\hline Magnesium & $2.83 \mathrm{~b}$ & $2.69 \mathrm{bc}$ & $3.60 a$ & $2.78 \mathrm{c}$ & 17.4 \\
\hline Calcium & $11.49 a$ & $11.26 a$ & $10.42 a$ & $10.83 a$ & 16.0 \\
\hline Sulfur & $0.97 b$ & $1.03 a b$ & $0.99 b$ & $1.20 \mathrm{a}$ & 21.1 \\
\hline \multicolumn{6}{|l|}{ Micronutrients } \\
\hline Manganese & $36.42 \mathrm{ab}$ & $32.37 b$ & $46.25 a$ & $39.37 a b$ & 28.7 \\
\hline Copper & 88.79ab & $89.50 a$ & $79.62 b$ & 87.00ab & 12.3 \\
\hline Iron & $90.12 a$ & $50.50 a$ & $66.25 a$ & $76.75 a$ & 10.9 \\
\hline Zinc & $89.91 a$ & $89.50 a$ & $79.62 b$ & 87.00ab & 12.2 \\
\hline
\end{tabular}

Means followed by the same letter on the line do not differ at $5 \%$ significance. On transplant date, seedlings were 10 days old from the establishment of cuttings in $\mathrm{KNO}_{3}$ solution.

In all treatments evaluated, major compounds of essential oil were menthol and menthone. Biosynthesis of menthol follows a series of metabolic pathways, under the action of enzymes responsible by its production (Maia, 1998). Essential oils with more than $20 \%$ of menthone indicate that its conversion to menthol did not happened yet. This conversion is a slow process and is associated to plant maturation and nutrition (Murray et al.,1972). As shown in Tables 4 and 5 , treatment $65 \% \mathrm{~N} / 50 \% \mathrm{P} / 25 \% \mathrm{~K} / 100 \% \mathrm{Mg}$ led, on average, to higher menthol levels and lower menthone levels, indicating that these plants had faster development when compared to other treatments, and consequently, a faster conversion of other components to menthol.

The environmental conditions can redirect metabolic pathways, affecting biosynthesis of several compounds (Moraes, 2009). Nutrition is one of the external factors that can affect qualitatively and quantitatively the production of some secondary metabolites (Lima et al., 2003). Although for $M$. piperita the direct function of macronutrients is not yet documented some studies indicates that the variation of nutrient levels in nutritive solution causes different yield and composition of essential oil (Mairapetyan et al., 1999; David et al., 2006; Valmorbida et al., 2006; David et al., 2007; Valmorbida and Boaro, 2007; Valmorbida et al., 2007). These variations may be associated with a greater leaf development and the emergence of new organs, concomitant to a steady content of secondary metabolites (Gobbo-Neto e Lopes, 2007). Mineral nutrition influences Carbon

Rev. Bras. Pl. Med., Campinas, v.16, n.1, p.97-106, 2014. 
metabolism directly and indirectly, because of its influence on growth and morphogenesis. Nitrogen affects positively biomass production, because of several physiological factors that contributes to synthesis of carbohidrates, aminoacids and nucleic acids (Maia, 1998). This element in linked to photosythesis metabolism and its equilibrium is essential for all steps of Calvin-Benson cycle (Salisbury Ross, 1992; Lawlor, 1993).

Phosphorus is incorporated to several organic compounds such as pentose-phosphates, fosfolipids, and nucleotides (Malavolta ,1997; Zeiger, 2004; Marschner, 2012). It also plays important roles in the regulation of Calvin-Benson cycle and transport of metabolites and assimilated compounds (Larcher, 2006).

Potassium activates enzymatic reactions such as P-transferase, acetate-kinase, piruvatekinase, and hydrolysis reactions. It also promotes synthesis of ribulose-biphosphate-carboxilase, which affects $\mathrm{CO}_{2}$ assimilation. It is essential for activation of ATPase that is needed for the exchange of nutrients and metabolites among apoplasts and simplasts (Wilkinson, 1994). Magnesium has specific roles on activation o enzymes related to respiration, DNA and RNA synthesis and in photosynthesis, as a component of chlorophyll molecule (Hinkle and Eisennenger, 1950; Zeiger, 2004).

All nutrient functions referred here are related to primary metabolism, but secondary metabolism may also be affected directly by the role of these nutrients upon enzymes of the mevalonic acid pathway and terpenoids production (Zeiger, 2004).

It must also be emphasized that treatment $65 \% \mathrm{~N} / 50 \% \mathrm{P} / 25 \% \mathrm{~K} / 100 \% \mathrm{Mg}$ was defined based on the studies of Leal (2001), Valmorbida et al. (2003) and David et al. (2006 and 2007), who evaluated the development of $M$. piperita subjected to a variation in $\mathrm{N}, \mathrm{K}$ and $\mathrm{P}$, respectively. The best level for each nutrient in the above-mentioned studies was used to establish treatment $65 \% \mathrm{~N} / 50 \% \mathrm{P} / 25 \% \mathrm{~K} / 100 \% \mathrm{Mg}$, with variation in $\mathrm{N}, \mathrm{P}$ and $\mathrm{K}$, keeping $\mathrm{Mg}$ at the complete level.

Leal (2001), Valmorbida et al. (2006) and David et al. (2007) observed higher menthol levels in plants grown with $100 \% \mathrm{~N}, 25 \% \mathrm{~K}$ and $50 \% \mathrm{P}$, respectively. The results found in those studies and in the present study showed the influence of mineral nutrition on the production and composition of $M$. Piperita essential oil.

As shown in Table 5, regardless of the

TABLE 4. Comparison among means of menthol production (\%) in the essential oil of Mentha piperita L. grown in nutrient solution with different levels of $\mathrm{N}, \mathrm{P}, \mathrm{K}$ and $\mathrm{Mg}$ at several harvests.

\begin{tabular}{|c|c|c|c|c|c|}
\hline \multirow{2}{*}{$\begin{array}{l}\text { N/P/K/Mg levels relative to the complete } \\
\text { solution }\end{array}$} & \multicolumn{5}{|c|}{ Harvest (Days after transplant) } \\
\hline & $1^{\text {st }}(69)$ & $2^{\text {nd }}(84)$ & $3^{\text {rd }}(98)$ & $4^{\text {th }}(113)$ & $\mathrm{N} / \mathrm{P} / \mathrm{K} / \mathrm{Mg}$ mean levels \\
\hline $50 \% \mathrm{~N} / \mathrm{P} / \mathrm{K} / 25 \% \mathrm{Mg}$ & $38.988 \mathrm{a}$ & $29.672 \mathrm{a}$ & $33.310 a b$ & $33.700 \mathrm{a}$ & $33.918 \mathrm{a}$ \\
\hline $50 \% \mathrm{~N} / \mathrm{P} / \mathrm{K} / \mathrm{Mg}$ & $44.848 \mathrm{a}$ & $29.082 \mathrm{a}$ & $39.253 \mathrm{a}$ & $28.087 \mathrm{a}$ & $35.318 \mathrm{a}$ \\
\hline $65 \% \mathrm{~N} / 50 \% \mathrm{P} / 25 \% \mathrm{~K} / 100 \% \mathrm{Mg}$ & $47.843 \mathrm{a}$ & $29.880 \mathrm{a}$ & $38.425 \mathrm{a}$ & $27.377 a$ & $35.881 \mathrm{a}$ \\
\hline $100 \%$ N/P/K/Mg (complete) & $47.818 \mathrm{a}$ & $26.815 \mathrm{a}$ & $26.472 \mathrm{~b}$ & $26.852 \mathrm{a}$ & $31.989 \mathrm{a}$ \\
\hline Mean of harvests & 44.874 & 28.863 & 34.365 & 29.004 & 34.276 \\
\hline $\mathrm{CV}$ & 17,239 & 9,760 & 7,774 & 7,620 & \\
\hline
\end{tabular}

Means followed by the same letter on the line do not differ at $5 \%$ significance. On transplant date, seedlings were 10 days old from the establishment of cuttings in $\mathrm{KNO}_{3}$ solution.

TABLE 5. Comparison among means of menthone production (\%) in the essential oil of Mentha piperita L. grown in nutrient solution with different levels of $\mathrm{N}, \mathrm{P}, \mathrm{K}$ and $\mathrm{Mg}$ at several harvests.

\begin{tabular}{lllccc}
\hline $\begin{array}{l}\text { N/P/K/Mg levels relative to the complete } \\
\text { solution }\end{array}$ & \multicolumn{5}{l}{ Harvest (Days after transplant) } \\
\hline & $1^{\text {st }}(69)$ & $2^{\text {nd }}(84)$ & $3^{\text {rd }}(\mathbf{9 8})$ & $\mathbf{4}^{\text {th }}(\mathbf{1 1 3})$ & N/P/K/Mg mean \\
& 11.295 a & 11.657 a & $8.465 \mathrm{ab}$ & $2.365 \mathrm{a}$ & $\mathbf{8 . 4 4 6}$ \\
$50 \% \mathrm{~N} / \mathrm{P} / \mathrm{K} / 25 \% \mathrm{Mg}$ & $10.970 \mathrm{a}$ & $11.310 \mathrm{a}$ & $5.630 \mathrm{bc}$ & $3.182 \mathrm{a}$ & $\mathbf{7 . 7 7 3}$ \\
$50 \% \mathrm{~N} / \mathrm{P} / \mathrm{K} / \mathrm{Mg}$ & $10.585 \mathrm{a}$ & $9.105 \mathrm{a}$ & $4.927 \mathrm{c}$ & $5.375 \mathrm{a}$ & $\mathbf{7 . 4 9 8}$ \\
$65 \% \mathrm{~N} / 50 \% \mathrm{P} / 25 \% \mathrm{~K} / 100 \% \mathrm{Mg}$ & $13.305 \mathrm{a}$ & $14.592 \mathrm{a}$ & $11.312 \mathrm{a}$ & $2.270 \mathrm{a}$ & $\mathbf{1 0 . 3 7 0}$ \\
$100 \% \mathrm{~N} / \mathrm{P} / \mathrm{K} / \mathrm{Mg}$ (complete) & 11.539 & 11.666 & $\mathbf{7 . 5 8 4}$ & $\mathbf{3 . 2 9 8}$ & $\mathbf{8 . 5 2 2}$ \\
Mean of harvests & 24,696 & 23,911 & $\mathbf{2 1 , 7 3 8}$ & $\mathbf{3 4 , 7 0 7}$ & \\
\hline CV & &
\end{tabular}

Means followed by the same letter on the line do not differ at $5 \%$ significance. On transplant date, seedlings were 10 days old from the establishment of cuttings in $\mathrm{KNO}_{3}$ solution. 
treatment to which M. piperita was subjected, menthone level tended to decrease with the development. These results agree with those of Lima and Mollam (1952) and Leal (2001), who grew $M$. arvensis and $M$. piperita, respectively, and verified that menthone level decreased constantly as the plant grew.

Plants grown with the complete level of nutrients, i.e. $100 \% \mathrm{~N} / \mathrm{P} / \mathrm{K} / \mathrm{Mg}$, had slower development, similarly to the plants that received the lowest nutrient levels, $50 \% \mathrm{~N} / \mathrm{P} / \mathrm{K} / 25 \% \mathrm{Mg}$. The highest level of these nutrients seems to have damaged plant growth, delaying the cycle, as shown in Figures 1(a-c) and Figures 2(a-c). Ruiz (1997) reported that the nutrient solution number 2 of Hoagland and Arnon (1950) overestimates all nutrients used in its composition. According to Zeiger (2004), the elements in that solution were established at the highest level that do not produce symptoms of toxicity or salt stress; therefore, these levels may be several fold higher than those found in the soil surrounding the roots.

In conclusion, considering that this solution is not specific for M. Piperita, this study suggests its cultivation using reduced levels of $65 \%$ de N, $50 \%$ de $\mathrm{P}$ e $25 \%$ de $\mathrm{K}$, which achieve similar or even better results regarding development, production and quality of essential oil.

\section{REFERENCE}

CARMELLO, Q. A. C. Hidroponia. In: REUNIÃO BRASILEIRA DE FERTILIDADE DO SOLO E NUTRIÇÃO DE PLANTAS. 1992, Piracicaba, Anais... Piracicaba: Sociedade Brasileira de Ciências do Solo, 1992. p. 355-368.

CASTRO, H. G.; FERREIRA, F. A.; SILVA, D. J. H; MOSQUIM, P. R. Contribuição ao estudo das plantas medicinais: metabólitos secundários. Visconde do Rio Branco, MG: Editora Suprema. 2001.

CROTEAU, R.; JOHNSON, M.A. Biosynthesis of terpenoids in glandular trichomes. In: RODRIGUES, E.; HEALEY, P.L.; METHA, j.; eds. Biology and chemistry of plant trichomes. Plenum Press, New York, 1984. P. 133-186.

DAVID, E. F. S.; BOARO, C. S. F.; MARQUES, M. O. M. Rendimento e composição do óleo essencial de Mentha piperita L., cultivada em solução nutritiva com diferentes níveis de fósforo. Revista Brasileira de Plantas medicinais. v. 4, p. 183-188, 2006

DAVID, E. F. S.; BOARO, C. S. F.; MISCHAN, M. M. Desenvolvimento e rendimento de óleo essencial de menta (Mentha x piperita L.) cultivada em solução nutritiva com diferentes níveis de fósforo. Biotemas. v. 20 , p. $15-26,2007$

DAVID, E. F. S.; BOARO, C. S. F. DAVID. Translocação orgânica, produtividade e rendimento de óleo essencial de Mentha piperita L. cultivada em solução nutritiva com variação dos níveis de N, P, K e Mg. Revista Braileira de Plantas Medicinais. v.11, p.236-246, 2009

EPSTEIN, E. BLOOM, A. Metabolismo Mineral. InNutrição Mineral de Plantas: Princípios e Perspectiva. Planta. Londrina, 2006. p. 209-244.

FAGERIA, N. K.; BALIGAR, V. C. JONES, C. A. Field Crops and mineral nutrition. In FAGERIA, N. K.; BALIGAR, V. C. JONES, C. A. Growth and mineral nutrition of field crops. 1997. p. 1-10.

FURLANI, P. R.; SILVEIRA, L.C.P.; BOLONHEZI, D. FAQUIM, V. Cultivo Hidropônico de plantas. Campinas: Instituto Agronômico, 1999. 52 p. (Boletim técnico, 180)

GOBBO-NETO, L.; LOPES, N. Plantas medicinais: Fatores de influência no conteúdo de metabólitos secundários. Química Nova. v. 30, p. 374-381, 2007.

HENDRIKS H, ANDERSON-WILDEBOER Y, Engels G, Bos R, Woerdenbag H J 1997. Malay ethno-medico botany in Machang. Planta Med, v. 63, p. 356-369.

HOAGLAND, D.R.; ARNON, D. I. The water: culture method for growing plants without soil. Berkeley: California Agricultural Experiment Station, 1950.

LARCHER, W. Ecofisiologia Vegetal. São Carlos: RiMa, 2006. 550p.

LAWLOR, D.W. The chemistry of photosynthesis. IN: Photosynthesis: Molecular, Physiological and Environmental Processes. 2nd. ed. Hong Kong, 1993.

LEAL, F. P. Desenvolvimento, produção e composição de óleo essencial da Mentha piperita L., cultivada em solução nutritiva com diferentes níveis de nitrogênio. 2001. (Mestrado - área de concentração Produção Vegetal). Departamento de Produção vegetal, Faculdade de Ciências Agronômicas, UNESP, Botucatu.

LIMA HRP; KAPLAN MAC; CRUZ AVM. Influencia dos fatores abióticos na produção e variabilidade de terpenóides em plantas. Floresta e Ambiente , v.10, n. 2, p. 71-77, 2003.

LIMA, A. R.; MOLLAN, T. R. M. Nova variedade de Mentha arvensis L. Bragantia, v. 12, p. 277-284, 1952.

LORENZI, H.; MATOS, F. J. A. Plantas medicinais no Brasil: nativas e exóticas, São Paulo: Nova Odessa, Instituto Plantarum, 2002. 512p.

MAIA, N.B. Efeito da nutrição mineral na qualidade do óleo essencial da menta (Mentha arvensis L.) cultivada em solução nutritiva. In: CORREA JÚNIOR, C.; MING, L.C.; SCHEFFER, M.C. (Eds.). Plantas medicinais, aromáticas e condimentares: avanços na pesquisa agronômica. Botucatu: UNESP; 1998. p. 81-95.

MAIRAPETYAN, S. K. Aromatic plant culture in open-air hydroponics. Acta Horticulturae, v. 502, p. 33-36, 1999.

MALAVOLTA, E.; Vitti, G.C.; Oliveira, S.A. Avaliação do estado nutricional das plantas: princípios e aplicações. Piracicaba: Potafos, 1997, 319p.

MARENCO, R. A. GONÇALVES, J. F. C. VIEIRA, G. Photosynthesis and leaf nutrient contents in Ochroma pyramidae (Bombacaceae). Photosynthetica, v. 39, n. 4, p. 539-543, 2001.

MARSCHNER, H. Functions of mineral nutrients: macronutrients. In: MARSCHNER, H. Mineral nutrition of higher plants. San Diego: Academic Press, 2012.

MARTINS, G. B. M. Estudos de microscopia óptica e de microscopia eletrônica de varredura em folhas de 
Mentha spicata e de Mentha spicata $\mathrm{x}$ suaveolens (Lamiaceae). Bragantia,v. 61, p.205-218, 2002.

MILTHORPE, F. L.; MOORBY, J. Some aspects of overall growth and its modification. In: MILTHORPE, F. L.; MOORBY, J. An introduction to crop physiology. London: Cambridge Univ. Press, 1974, p.152-179.

MORAIS L. Influência dos fatores abióticos na composição química dos óleos essenciais. Horticultura Brasileira. V. 7. p. 4050-4063, 2009.

MURRAY, M. J.; FAAS, W.; MARBLE, P. Chemical composition of Mentha arvensis var. piperascens and four hybrids with Mentha crispa arvested at different times in Indiana and Michigan. Crop Science, v.12, p.742-5, 1972.

RUIZ, H. A. Relações molares de macronutrientes em tecidos vegetais como base para formulação de soluções nutritivas. Ceres, v.44, n. 255, p. 533-546, 1997.

SALISBURY, F. B., ROSS, W. C. Crbon dioxide fixation and carbohydrate synthesis. In: Plant physiology. California:Wadsworth Publishing, 1992.

SANTOS et al. Diferentes concentrações de solução nutritiva para a cultura de alfavaca (Ocimum basilicum) em sistema de cultivo hidropônico. In: CONGRESSO BRASILEIRO DE OLERICULTURA, v. 20. n. 20, 2002, Uberlândia: Anais... Uberlândia: Sociedade de Olericultura do Brasil; 2002. CD-ROM.

SOARES, A.; SACRAMENTO, L. V. S. Desempenho de
Mentha spp quanto a formação de raízes adventícias em função do substrato. In: JORNADA PAULISTA DE PLANTAS MEDICINAIS, 5., 2001, Botucatu. Anais... Botucatu: Universidade Estadual Paulista, Campus de Botucatu; 2001. p. 24-29

VALMORBIDA, J.; BOARO, C. S. F.; MARQUES, M.O.M.; FERRI, A. F. Rendimento e composição química de óleos essenciais de Mentha piperita L. cultivada em solução nutritiva com diferentes concentrações de potássio. Revista Brasileira de Plantas Medicinais, v. 8, p. 56-61, 2006.

VALMORBIDA, J.; BOARO, C. S. F.; SCAVRONI, J.; DAVID, E. F. S. Crescimento de Mentha piperita L. cultivada em solução nutritiva com diferentes doses de potássio. Revista Brasileira de Plantas Medicinais, v. 9, p. 27-31, 2007.

VALMORBIDA, J.; BOARO, C. S. F. Growth and Development of Mentha piperita L. in Nutrient Solution as Affected by Rates of Potassium. Brazilian Archives of Biology and Technology, v. 50, n. 3, p. 379-384, 2007.

WILKINSON, R.E. Plant: environment interactions. New York: Marcel Dekker, 1994.

ZAR, J.H. Biostatistical Analysis. Englewood Cliffs: Prentice - Hall International Editions; 2009.

ZEIGER, E. Nutrição mineral. In: TAIZ, L. ZIEGER, E. Fisiologia Vegetal. 3. ed. Porto Alegre: Artmed; 2004. p.95-105.

Rev. Bras. PI. Med., Campinas, v.16, n.1, p.97-106, 2014. 